www.jmscr.igmpublication.org

Impact Factor 5.244

Index Copernicus Value: 83.27

ISSN (e)-2347-176x ISSN (p) 2455-0450

crossref DOI: _https://dx.doi.org/10.18535/jmscr/v4i11.114

Journal Of Medical Science And Clinical Research

\title{
Evaluation of Thyroid Function Status in Patients with Chronic Kidney Disease
}

\author{
Author \\ Manasa.A.S.Gowda \\ MRMC, Gulbarga \\ Email: manasa.asg5@gmail.com, Mobile: 9886212280
}

\begin{abstract}
Chronic Kidney Disease is a worldwide health problem with an increasing incidence and prevalence. Abnormalities in the structure and function of the thyroid gland and in the metabolism and plasma concentration of thyroid hormones are common in patients with Chronic Kidney Disease. In view of variability of thyroid function tests in patients with CKD in previous studies, a prospective study of various thyroid functions is undertaken to establish a correlation if any between thyroid dysfunction and severity of renal diseases.

Method: A prospective study was conducted on 50 patients with Chronic Kidney Disease on conservative management. Quantitative determination of $T_{3}, T_{4}, T S H$ was done by Enzyme Linked Immunosorbent Assay and data were analyzed.

Results: 24 patients had low T3 syndrome $(0.2-1.9 \mathrm{ng} / \mathrm{ml}$, mean 0.665$)$ which accounts for $48 \%$ of the patients, 11 patients had low T4 syndrome $(0.5-9.5 \mu \mathrm{g} / \mathrm{ml}$, mean 5.631) which accounts for $22 \%$ of the patients and 5 patients

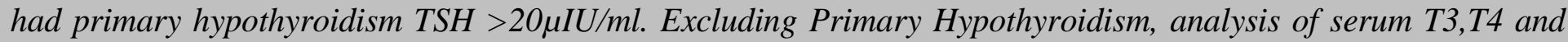
TSH in the study subjects shows very high significance $\chi^{2}=20.82, p<0.001$. Distribution of Thyroid Dysfunction in this study among various creatinine clearance levels showed that as glomerular filtration rate declines, number of patients with low T3 syndrome increased $\chi^{2}=8.47, p<0.05$, significant difference. In patients with low T3 syndrome, the mean values of TSH in various stages of renal disease are within normal range mean 4.85, values of TSH did not show any linear correlation with GFR. Number of patients with low T4 syndrome did not correlate with severity of renal disease. Thyroid Dysfunction occurred in 58\% of the patients with chronic kidney disease in our study.

Conclusion: Thyroid dysfunction does not indicate a state of hypothyroidism, but a reflection of the state of chronic illness/malnutrition. The low T3 state of CKD can be viewed as being protective, promoting conservation of protein. The number of patients with low T3 syndrome progressively increases with the severity of renal failure.
\end{abstract}

\section{Introduction}

Chronic kidney disease includes a spectrum of distinct pathophysiological forms which is linked with abnormal kidney function and a progressive decrease in glomerular filtration rate $e^{1,2}$ CKD is a clinical syndrome due to irreversible loss of renal function leading to metabolic, endocrine, excretory and synthetic failure resulting in accumulation of non - protein nitrogenous substances and present with various clinical manifestations.

CKD is the final common pathway of irreversible loss of nephrons at last bringing about change of - milieu interior\| influencing each framework in the body including thyroid hormonal framework. The elements of thyroid and kidney are interrelated ${ }^{3-6}$ 
The association amongst kidney and thyroid functions is known for years ${ }^{7-10 .}$ Thyroid hormones (TH) are essential for growth and development of the kidney and for the maintenance of fluid and electrolyte homeostasis. On the other hand, kidney is engaged in the metabolism and elimination of $\mathrm{TH}$. The decrease of kidney function is accompanied by changes in the synthesis, secretion, metabolism, and elimination of $\mathrm{TH}$. Thyroid dysfunction gains unique characteristics in those individuals with advanced kidney disease ${ }^{11}$.

Chronic kidney disease is connected with thyroid function abnormalities leading to low levels of serum total and free $\mathrm{T} 3$ concentration and distinctive reverse T3 and free T4 levels. The TSH levels are practically typical in most patients and observed to be in euthyroid state. Besides, thyroid diseases, including goiter, hypothyroidism, thyroid nodules and thyroid cancer, may happen more frequently in ESRD individuals than in the all inclusive community and may be under diagnosed due to limited clinical awareness. ${ }^{12-13}$

Several studies have been conducted to study thyroid function abnormalities in chronic kidney disease patients. All abnormalities like hypothyroidism, hyperthyroidism and euthyroid state have been reported in the studies done earlier. The relation between severity of renal failure and thyroid dysfunction is not clear. The estimated problem of hypothyroidism is between 0-9 percent in end stage renal disease. In ESRD increased prevalence of thyroid swelling (goitre) has also been noted.

\section{Aim}

- To study the prevalence of thyroid dysfunction in patients with chronic kidney disease.

- To study the correlation between thyroid dysfunction and severity of renal diseases.

- To differentiate primary thyroid diseases from thyroid dysfunction due to chronic kidney disease.

\section{Methodology}

Methods of collection of data

Study subjects: A prospective study was conducted on 50 patients of whom were diagnosed to have chronic kidney disease and being admitted in Basaveshwar Teaching \& General Hospital, Gulbarga during the period of January 2011 to June 2012. These samples were selected by using simple random sampling method. Statistical parameters mean, standard deviation (SD) and correlations were used and parametric and non parametric tests were used for the analysis. Informed consent was obtained from all the patients.

Inclusion criteria: Patients with chronic kidney disease fulfilling the criteria for CKD and who are on conservative management were included in the study.

Criteria for Chronic Kidney Disease were symptoms of uremia for 3 months or more. Elevated blood urea, serum creatinine and decreased creatinine clearance. Ultra sound evidence of chronic kidney disease are Bilateral contracted kidneys - size less than $8 \mathrm{~cm}$ in male and size less than $7 \mathrm{~cm}$ in female. Poor corticomedullary differentiation. Type 2 or 3 renal parenchymal changes. Supportive laboratory evidence of CKD like anemia, low specific gravity, changes in serum electrolytes, etc., radiological evidence of renal osteodystrophy

Exclusion criteria are patients on peritoneal dialysis or hemodialysis. Nephrogenic range of proteinuria. Low serum protein especially albumin. Other conditions like acute illness, recent surgery, trauma or burns, diabetes mellitus, liver diseases, drugs altering thyroid profile like amiodarone, steroids, dopamine, phenytoin, betablocker, estrogen pills, iodine-containing drugs.

Diagnostic test: Clinical history and clinical examination was undertaken with preference to thyroid and renal diseases. The following investigations such as urine routine and microscopic examination, peripheral smear for anemia and burr cells, renal parameters like blood urea, serum creatinine and creatinine clearance (using Cockcroft - Gault formula). Serum 
electrolytes including calcium and phosphorous, serum cholesterol, 24 hours urine protein and serum protein ECG, chest $\mathrm{X}$ and $2 \mathrm{D}-\mathrm{ECHO}, \mathrm{X}$ ray wrist, forearm and spine for evidence of renal osteodystrophy, USG abdomen for evidence of chronic kidney disease, FNAC in patients presenting with thyroid swelling. After selecting the patients, fulfilling the above criteria, about 5 $\mathrm{ml}$ of blood sample is collected in non-heparinised serum bottle and sent for thyroid profile.

Components considered for thyroid profile in this study were serum triiodothyronine $\left(\mathrm{T}_{3}\right)$, serum thyroxine $\left(\mathrm{T}_{4}\right)$, serum thyroid stimulating hormone (TSH).Quantitative determination of $\mathrm{T}_{3}, \mathrm{~T}_{4}, \mathrm{TSH}$ is done by Enzyme Linked Immunosorbent Assay.50 patients with Chronic Kidney Disease (CKD) fulfilling the criteria for CKD who were on conservative management were studied.

\section{Results}

Among these 50 patients 39 were male and 11 were female, their age varied from 12-70 years, of these 50 patients, patients who were 30 years old and below were 8 , between 30-60 years were 25 and patients above the age of 60 years were 6 in number.

Of the 50 patients, 21 patients had GFR of $<10 \mathrm{ml} / \mathrm{min}$ accounting to $42 \%, 19$ patients had GFR ranging from 11-20 $\mathrm{ml} / \mathrm{min}$ accounting for another $38 \%$ and the remaining 10 patients had GFR $>20 \mathrm{ml} / \mathrm{min}$ accounting for $20 \%$. Blood urea varied from $64-177 \mathrm{mg} / \mathrm{dl}$ and creatinine levels varied from $3 \mathrm{mg}-17.2 \mathrm{mg} / \mathrm{dl}, 24$ hours urine protein excretion was $<1 \mathrm{~g} /$ day in all the patients in our study.
Serum calcium and phosphorous were normal in all our patients, $80 \%$ of the patients had anaemia with peripheral smear revealing normocytic normochromic anaemia in $72 \%$ and hypochromic anaemia in $8 \%$ of the patients.

Burr cells were present in $40 \%$ of the cases, one patient had pleural effusion in our study, two patients in the study showed evidence of osteodystrophy and none of the patients had pericardial effusion. Ultrasound abdomen showed evidence of CKD in all patients, contracted kidney was present in $90 \%$ of the patients, remaining patients had poor corticomedullary differentiation. Among the 50 patients in our study 24 of them had low serum $\mathrm{T}_{3}$ levels (48\%), 5 patients among the low serum $\mathrm{T}_{3}$ level also had high TSH value of $>20 \mu \mathrm{IU} / \mathrm{ml}$ with low $\mathrm{T}_{4}$ levels and also symptoms suggestive of hypothyroidism.

Therefore these 5 patients were grouped under "Primary Hypothyroidism" as per the criteria (10\%). 11 patients had low $\mathrm{T}_{4}$ levels accounting for $22 \%$ of the patients.

Symptoms of hypothyroidism such as tiredness, somnolence, weight gain, cold intolerance, hoarseness of voice etc were also studied in the sample population. $72 \%, 36$ patients had the symptoms as shown in (Table 1). 17 patients of the 24 who had low $\mathrm{T}_{3}$ syndrome had symptoms accounting for $70.83 \%$ and 5 patients among who were hypothyroid had symptoms accounting for 100\%. 21 patients with CKD did not show thyroid dysfunction, among these 21 patients 14 of them had symptoms of hypothyroidism which accounts to $66.67 \%$.

Table-1: Analysis of hypothyroid symptoms in CKD

\begin{tabular}{|l|c|c|}
\hline Variants & $\begin{array}{c}\text { No. of patients } \\
\text { with symptoms }\end{array}$ & Percentage \\
\hline Low $\mathrm{T}_{3}$ Syndrome $(\mathrm{n}=24)$ & 17 & $70.83 \%$ \\
\hline Hypothyroidism $(\mathrm{n}=5)$ & 5 & $100 \%$ \\
\hline CKD without thyroid dysfunction $(\mathrm{n}=21)$ & 14 & $66.67 \%$ \\
\hline Total $(50)$ & 36 & $72 \%$ \\
\hline
\end{tabular}

Dry, flaky skin was present in 15 patients of which only 4 patients were hypothyroid, sinus bradycardia was present in 7 patients of which only 2 patients were hypothyroid, delayed ankle jerk was present in 8 patients of which only 2 patients were hypothyroid. 


\section{JMSCR Vol||04||Issue||11||Page 14235-14241||November}

Hypothyroidism did not show any linear correlation with GFR. increased number of hypothyroid patients of about 4 in number were present in GFR $11-20 \mathrm{ml} / \mathrm{min}$ whereas only 2 patients had hypothyroidism in GFR $<10 \mathrm{ml} / \mathrm{min}$. None of the patients in our study had diffuse thyroid swelling.
Age incidence of low $\mathrm{T}_{3}$ syndrome was done in this study as shown in (Table 2), it showed that $30 \%$ of the CKD patients who had low $\mathrm{T}_{3}$ level were 30 years of age or below and $54.8 \%$ of the patients were between the ages 31-60 years, as the age increased the number of patients with low $\mathrm{T}_{3}$ also increased, $44.4 \%$ of the patients with low $\mathrm{T}_{3}$ were above the age of 60 years

Table-2: Age incidence of Low $\mathrm{T}_{3}$ syndrome in this study

\begin{tabular}{|l|c|c|c|}
\hline Age in years & No of patients & Low $\mathbf{T}_{3}$ syndrome & Percentage \\
\hline$<30$ & 10 & 3 & $30 \%$ \\
\hline $31-60$ & 31 & 17 & $54.8 \%$ \\
\hline$>60$ & 9 & 4 & $44.4 \%$ \\
\hline total & 50 & 24 & $48 \%$ \\
\hline
\end{tabular}

Sex incidence of low $\mathrm{T}_{3}$ syndrome in one study showed that $51.3 \%$ of males had low $\mathrm{T}_{3}$ and $38.7 \%$ of the females have low $\mathrm{T}_{4}$ syndrome (Table 3 ). The $\mathrm{T}_{3}$ levels varied from $0.2-1.9 \mathrm{ng} / \mathrm{ml}$ (Fig 1 ), the mean value being 0.665. Excluding the patients with primary hypothyroidism, the mean value was 0.706 , this value was in low normal limit. Excluding hypothyroidism $\mathrm{T}_{3}$ levels were studied in relation to GFR, mean value of serum $\mathrm{T}_{3}$ was low $(0.534 \mathrm{ng} / \mathrm{ml})$ only in patients with GFR
$<10 \mathrm{ml} / \mathrm{min}$ (Table 5). The mean value was low normal in patients with GFR $>10 \mathrm{ml} / \mathrm{min}$. According to our study, number of patients with low $\mathrm{T}_{3}$ increased with increase in the severity of renal failure (Table 6) in spite of low $\mathrm{T}_{3}$. The serum $\mathrm{T}_{4}$ levels varied from $0.5-9.5 \mu \mathrm{g} / \mathrm{dl}$. Mean value of serum $\mathrm{T}_{4}$ among 50 patients was 5.631, excluding hypothyroidism patients the mean value was $5.98 \mu \mathrm{g} / \mathrm{ml}$. this value is within low normal level of $\mathrm{T}_{4}$.

Table-3: Sex incidence of low $\mathrm{T}_{3}$ syndrome in this study

\begin{tabular}{|l|c|c|c|}
\hline Sex & No. of patients & $\begin{array}{c}\text { Low } \mathbf{T}_{3} \\
\text { Syndrome }\end{array}$ & Percentage \\
\hline Male & $39(78 \%)$ & 20 & $51.3 \%$ \\
\hline Female & $11(22 \%)$ & 4 & $38.7 \%$ \\
\hline Total & $50(100 \%)$ & 24 & $48 \%$ \\
\hline
\end{tabular}

$\mathrm{X}^{2}=0.78, \mathrm{p}<0.05, \mathrm{NS}$

Figure-1: Serum concentration of thyroid hormone

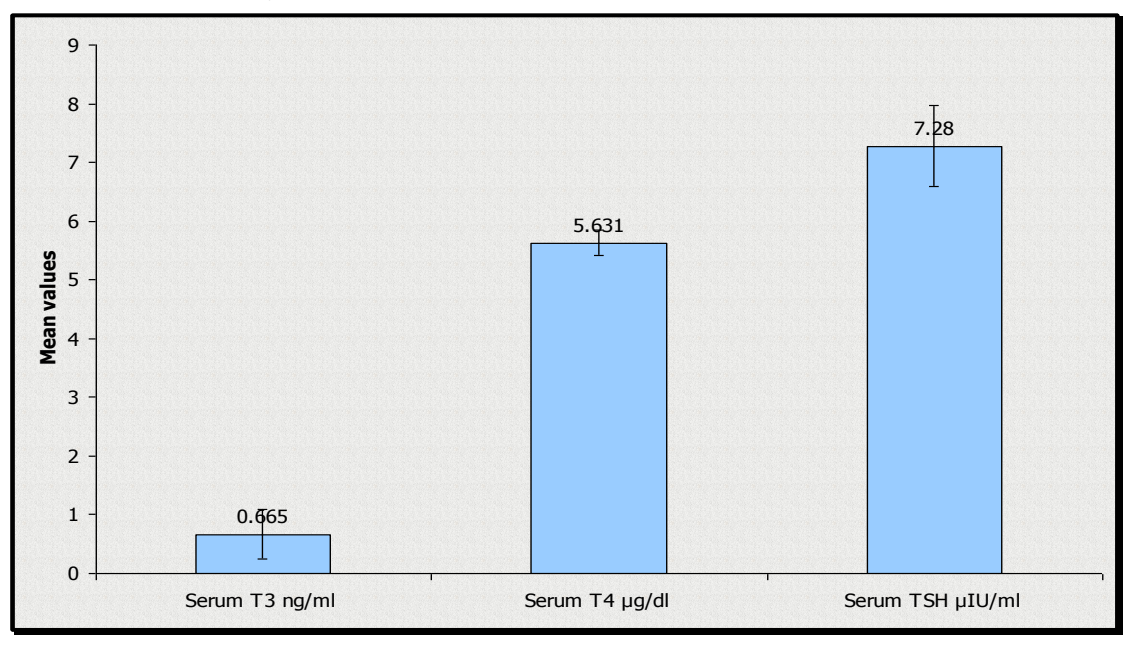


Table-5: Distribution of thyroid dysfunction in this study among various creatinine clearance levels

\begin{tabular}{|l|c|c|c|c|c|c|}
\hline \multirow{2}{*}{$\begin{array}{l}\text { Creatinine } \\
\text { Clearance mi/mm }\end{array}$} & \multicolumn{2}{|c|}{$\begin{array}{c}\text { No. of } \\
\text { Patients }\end{array}$} & \multicolumn{2}{c|}{$\begin{array}{c}\text { Low T } \\
\text { Syndrome }\end{array}$} & \multicolumn{2}{|c|}{ Hypothyroidism } \\
\cline { 2 - 7 } & No. & Percent & No. & Percent & No. & Percent \\
\hline$<10$ & 21 & 42.00 & 14 & 66.67 & 3 & 14.3 \\
\hline $11-20$ & 19 & 38.00 & 7 & 36.84 & 2 & 10.50 \\
\hline$>20$ & 10 & 20.00 & 3 & 30.00 & 0 & 0.00 \\
\hline$X^{2}=8.47, \mathrm{p}>0.05$ significant
\end{tabular}

Table-6: Analysis of hypothyroid symptoms in CKD

\begin{tabular}{|l|c|c|}
\hline Variants & $\begin{array}{c}\text { No. of patients } \\
\text { with symptoms }\end{array}$ & Percentage \\
\hline Low $\mathrm{T}_{3}$ Syndrome $(\mathrm{n}=24)$ & 17 & $70.83 \%$ \\
\hline Hypothyroidism $(\mathrm{n}=5)$ & 5 & $100 \%$ \\
\hline CKD without thyroid dysfunction $(\mathrm{n}=21)$ & 14 & $66.67 \%$ \\
\hline Total $(50)$ & 36 & $72 \%$ \\
\hline
\end{tabular}

Excluding 5 hypothyroid patients who have low $\mathrm{T}_{4}$ level below normal and low $\mathrm{T}_{3}$ syndrome (Table values, 11 other patients accounting to $22 \%$ had $\mathrm{T}_{4}$ 7).

Table-7: Analysis of thyroid dysfunction in this study

\begin{tabular}{|l|c|c|}
\hline Thyroid dysfunction & No. of Patients & Percentage \\
\hline Low $\mathrm{T}_{3}$ syndrome & 24 & $48 \%$ \\
\hline Low $\mathrm{T}_{4}$ syndrome & 11 & $22 \%$ \\
\hline Hypothyroidism & 5 & $10 \%$ \\
\hline
\end{tabular}

Number of patients with low $\mathrm{T}_{4}$ does not correlate with the severity of renal disease (Table 8). The mean value of $\mathrm{T}_{4}$ excluding hypothyroidism patients was normal at all stages of CKD (Table 9). None of the patients had $\mathrm{T}_{4}$ values above normal level. The TSH values varied from $0.6-27$ $\mu \mathrm{IU} / \mathrm{ml}$ with mean value of $7.28 \mu \mathrm{IU} / \mathrm{ml}$, excluding hypothyroidism mean value was 4.85 . This shows normal serum level of TSH.

Table-8: Distribution of low $\mathrm{T}_{3}$ and $\mathrm{T}_{4}$ syndrome in this study

\begin{tabular}{|l|c|c|c|c|c|}
\hline Creatinine & \multirow{2}{*}{$\begin{array}{c}\text { No. of } \\
\text { Clearance } \mathbf{~ m l} / \mathbf{m m}\end{array}$} & \multicolumn{2}{c|}{ Low T $\mathbf{3}_{\mathbf{3}}$ Syndrome } & \multicolumn{2}{c|}{ Low T $\mathbf{T}_{\mathbf{4}}$ Syndrome } \\
\cline { 3 - 6 } & patients & No. & Percent & No. & Percent \\
\hline$<10$ & 21 & 14 & $66.67 \%$ & 7 & $31.3 \%$ \\
\hline $11-20$ & 19 & 7 & $36.84 \%$ & 3 & $15.82 \%$ \\
\hline$>20$ & 10 & 3 & $30 \%$ & 1 & $10 \%$ \\
\hline
\end{tabular}

Table-9: Distribution of thyroid dysfunction in this study among various creatinine clearance levels

\begin{tabular}{|l|c|c|c|c|c|c|}
\hline \multirow{2}{*}{$\begin{array}{l}\text { Creatinine } \\
\text { Clearance mi/mm }\end{array}$} & \multicolumn{2}{|c|}{$\begin{array}{c}\text { No. of } \\
\text { Patients }\end{array}$} & \multicolumn{2}{c|}{$\begin{array}{c}\text { Low T } \\
\text { Syndrome }\end{array}$} & \multicolumn{2}{|c|}{ Hypothyroidism } \\
\cline { 2 - 7 } & No. & Percent & No. & Percent & No. & Percent \\
\hline$<10$ & 21 & 42.00 & 14 & 66.67 & 3 & 14.3 \\
\hline $11-20$ & 19 & 38.00 & 7 & 36.84 & 2 & 10.50 \\
\hline$>20$ & 10 & 20.00 & 3 & 30.00 & 0 & 0.00 \\
\hline
\end{tabular}

Among the 50 patients, TSH was normal in 38 patients $(76 \%)$ and values between $7.1-20 \mu \mathrm{IU} / \mathrm{ml}$ in 7 patients $(14 \%)$. It was elevated $>20 \mu \mathrm{IU} / \mathrm{ml}$ in 5 patients $(100 \%)$ of which 3 were female and 2 were male. According to our study, in patients with low $\mathrm{T}_{3}$ syndrome, the mean values of TSH in various stages of renal disease are within normal range, values of TSH did not show any linear correlation with GFR.

\section{Discussion}

In our study, patients only on conservative management were studied. This is because thyroid profile undergoes changes due to dialysis 
independent of that due to chronic kidney disease. Dialysis also changes the previous serum status of thyroid hormone in the patients with renal failure. Many studies have been conducted by comparing CKD patients on conservative Management and patients on hemodialysis by Ramirez ${ }^{14}$ and Kayima et $\mathrm{a} 1^{15}$.

As with other studies, mean $\mathrm{T}_{3}$ level in our study was reduced below normal in GFR less than 10 $\mathrm{ml} / \mathrm{min}$. In higher GFR, it was present in low normal and there was no linear correlation between $T_{3}$ level and GFR, which is consistent with Avasthi et al study ${ }^{16}$.

Mean $\mathrm{T}_{4}$ level in our study was within normal limits in all levels of GFR, but it is in low normal level and also it does not correlate with the severity of renal failure.

In our study, not all the patients with CKD have low $\mathrm{T}_{3}$ and $\mathrm{T}_{4}$. It is estimated that only 58\% (29 patients) of patients have Thyroid Profile abnormality. Remaining $42 \%$ of patients have normal thyroid profile.

Among 58\% of these patients excluding primary hypothyroidism patients $28 \%$ have only low $\mathrm{T}_{3}$ level with normal $\mathrm{T}_{4}$ level. Remaining $20 \%$ have both low $\mathrm{T}_{3}$ and $\mathrm{T}_{4}$ level. The percentage of patients having low $T_{3}$ and $T_{4}$ gradually increase with decrease in GFR. The patients who will develop such changes in thyroid profile is not known.

Excluding hypothyroidism, mean TSH level in our study was within normal limits. The mean TSH levels are also within normal limits for the various ranges of GFR. But TSH level doesn't show any linear correlation with the severity of renal failure. This is consistent with the study conducted by Spector and Ramirez et al ${ }^{17,14}$. These studies demonstrated abnormality in hypophyseal mechanism of TSH release in uraemic patients as the TSH response to the TRH was blunted.

In our study, excluding those with hypothyroiddism, seven patients had mild elevation of TSH with low $\mathrm{T}_{3}$ level. Among these patients, $\mathrm{T}_{4}$ is within normal limits in 4 of the patients. In the remaining 3 patients $T_{4}$ is below normal. There were no clinical features suggestive of hypothyroidism in these patients. Investigations like $\mathrm{FT}_{4}, \mathrm{FT}_{3}, \mathrm{TRH}$ response and anti thyroid auto antibodies can be done to diagnose hypothyroiddism in these patients.

Our study is consistent with the results of Ramirez et a ${ }^{14}$ study showing low T3, low T4 and normal or mild elevation of TSH. Yet it is unclear that to what extent these changes are responsible for the manifestations of Uraemic syndrome. From the various studies it has been suggested that this thyroid profile derangements is a part of body adaptation mechanism.

Previous studies by Quion verde et $\mathrm{a} 1^{18}$ reported high prevalence of hypothyroidism in CKD. It was estimated to be about $5 \%$ in patients with terminal renal failure. In our study, hypothyroidism is present in $10 \%$ of the patients but doesn't correlate with the severity of the renal failure. The symptoms of hypothyroidism were distributed equally in both hypothyroid and CKD patients in our study. Signs of hypothyroidism were more common in CKD without hypothyroidism than with hypothyroidism.

So, diagnosis of hypothyroidism in CKD mainly rest on TSH level which should be very high (>20 $\mu \mathrm{IU} / \mathrm{dl}$ ) with low serum $\mathrm{T}_{4}$. In this study none of the patients had clinical or biochemical features of hyperthyroidism.

\section{Conclusion}

In patients with CKD, thyroid dysfunction occured in $58 \%$ of the patients. Incidence of hypothyroidism is increased in patients with chronic kidney disease. Number of patients with low $\mathrm{T}_{3}$ and $\mathrm{T}_{4}$ syndrome progressively increased with the severity of chronic kidney disease. Serum level of $T_{3}$ and $T_{4}$ had no correlation with the severity of chronic kidney disease.

\section{Limitations of the Study}

1) Thyroid dysfunction was studied in patients with CKD irrespective of the etiology of CKD therefore individual 
correlation of the etiology of CKD with thyroid dysfunction could not be assessed.

2) Thyroid dysfunction was not studied in patients on dialysis, as dialysis itself affects the thyroid profile independently of CKD.

\section{Acknowledgement}

I sincerely thank all the individuals who have supported me in this study.

\section{Reference}

1. Andrew S. Levey, Josef Coresh, Ethan Balk, Annamaria T. Kausz, Ronald D. Perrone. National Kidney Foundation Practice Guidelines for Chronic Kidney Disease: Evaluation, Classification, and Stratifiction. MD Ann Intern Med. 2003;139:137-147.

2. Joanne M.Bargman, Karl S.Korecki. Chronic kidney disease. In: Dan L.Lango, Anthony S.Fauci, Dennis Kasper et al. Harrison's Principles of Internal Medicine, Vol. 2, 18th edn., 2011; McGraw Hill, USA, pp. 2289-2293; 2308-2313.

3. Feinstein EI, Kaptein EM, Nicoloff JT \&Massry SG. Thyroid function in patients with nephrotic syndrome and normal renal function. American Journal of Nephrology 19822 70-76.

4. Kaptein EM, Quion-Verde H \&Massry SG. Hemodynamic effects of thyroid hormone. Contributions to Nephrology 198441 151-159.

5. Kaptein EM. Thyroid function in renal failure. Contributions to Nephrology 1986 50 64-72.

6. Robert W Schrier. Abnormalities in the thyroid gland and hypothalamo pituitary thyroid axis in patients with CKD Diseases of the kidney and urinary tract, eighth edition 2007; volume 3: page number 2518
7. Feinstein EI, Kaptein EM, Nicoloff JT \& Massry SG. Thyroid function in patients with nephrotic syndrome and normal renal function. American Journal of Nephrology 19822 70-76.

8. Kaptein EM, Quion-Verde H \& Massry SG. Hemodynamic effects of thyroid hormone. Contributions to Nephrology 198441 151-159.

9. Kaptein EM. Thyroid function in renal failure. Contributions to Nephrology 1986 $5064-72$.

10. Kaptein EM, Feinstein EI \& Massry SG. Thyroid hormone metabolism in renal diseases. Contributions to Nephrology 198233 122-135.

11. Kaptein EM, Quion-Verde H, Chooljian CJ, Tang WW, Friedman PE, Rodriquez HJ \& Massry SG. The thyroid in endstage renal disease. Medicine 198867 187-197.

12. Parameswaran S. Chronic kidney disease in India. Health Sci 2012;1:JS001

13. Kaptein EM. Thyroid hormone metabolism and thyroid disease in chronic renal failure. Endocrin Rev 1996;17:4563.

14. Ramirez $\mathrm{G}$ et al. Thyroid abnormalities in renal failure. A study of 53 patients on chronic dialysis. Ann Internal Medicine, 1973; 79, 500-4

15. Kayima JK et al. Thyroid hormones profile in patients with chronic renal failure on conservative management and regular hemodialysis. East Afr Med J, 1992; 69: 333-6.

16. Avasthi $\mathrm{G}$ et al. Study of Thyroid function in patients of chronic renal failure. Indian Journal of Nephrology, 2001; 11: 165-170.

17. Spector DA et al. Thyroid function and metabolic rate in chronic renal failure. Ann Intern Med. 1976; 85: 724-30

18. Quion-verde et al. Prevalence of thyroid disease in chronic renal failure and dialysis patients. IXt1' mt Congr of Nephrol, 1984; 120. 